\title{
Executive Director's Report
}

$\mathrm{n}$ this July/August 2005 issue of The

Forestry Chronicle, we are pleased to present our 2004-2005 Gold Medal Recipients. The Institute is proud to recognize the outstanding achievements of students through the awarding of a Gold Medal Award.

The Gold Medal Award is over 50 years old. K.G. Fensom noted in the Institute's "Expanding Forestry Horizons - A History of The Canadian Institute of Forestry/Institut forestier du Canada - 1908-1969" that "the idea of presenting a gold medal to a top flight forestry student at the University of British Columbia was discussed and approved at meetings of the Vancouver Section in 1949. Subsequently a design contest, won by M.W. Gormely, produced a round $10 \mathrm{~K}$ gold medal bearing a symbolic tree.

In 1951, Mr. Harry Dembicki of Trail, BC was the first recipient of the Canadian Institute of Forestry's (Vancouver and Vancouver Island) gold medal. The December 1952 issue of The Forestry Chronicle states, "This is a gold medal, the gift of the Vancouver and Vancouver Island Sections of the Canadian Institute of Forestry, which is awarded to the student in the graduating class in Forestry (BSF or BASc. course) who, in the opinion of the Faculty of Forestry, has made the best allaround record in professional forestry in all years at the University, and who has demonstrated a high quality of character, leadership, sportsmanship, and scholarship." Fensom notes "up to 1953, this medal, financed jointly by the
Vancouver and Vancouver Island Sections, was awarded annually to the graduating student at U.B.C. with the highest standing. In that same year a motion moved by J.W. Giles and seconded by R.S. Young was adopted at the annual general meeting of the Institute. It read - "That the Canadian Institute of Forestry undertake to provide annually a Gold Medal Award to the most deserving student of the graduating class in each of the four Canadian forest schools on a basis to be determined by the executive in consultation with the deans of the four forestry schools."

The original "Gold Medal Award" had on one side the words "Canadian Institute of Forestry — Award for Merit. On the reverse were the name, school and graduating year of the recipient. "The graduate who receives the award is selected by the Dean in consultation with other faculty members. This basis for selection is that the student must have an outstanding record through all years of his course, not only scholarship, but in extra-curricular activities including sports and other student activities."

Between the years 1954 to 1972, the sections associated with the University of New Brunswick, Laval University, and University of Toronto began awarding the gold medal. Then from 1973 to 1991 graduates from the remaining university forestry faculties received the gold medal. In 1992, in recognition of the technical schools and their graduates, the Gold Medal Award was provided to students graduating from each of

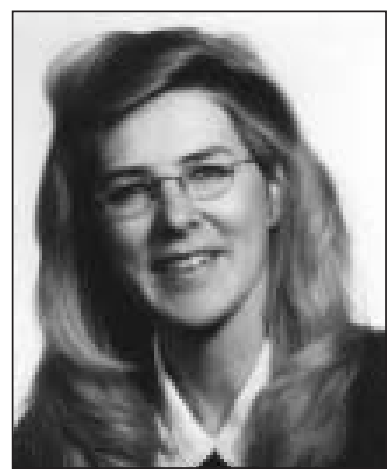

Roxanne Comeau R.P.F. CIF/IFC Executive Director/ Directrice générale

the seven university forestry faculties and the 21 forestry technical schools in Canada.

Over 50 years later, the criteria for the award have changed very little. The recipient is selected by the head of the school in recognition of outstanding scholarship, sportsmanship and citizenship throughout the years of the program. However, the award is no longer a $10 \mathrm{~K}$ gold medal. Today the "gold" medal is mounted on a wooden engraved plaque. The "Gold Medal" is usually awarded by a national or section representative during the school's Canadian Institute of Forestry Silver Ring ceremony.

Please take the time to read about the outstanding individuals who are presented on the following pages.

\section{References}

The Forestry Chronicle Vol. 28, December 1952, No. 4

Expanding Forestry Horizons - A History of the Canadian Institute of Forestry/Institut Forestier du Canada-1908-1969".

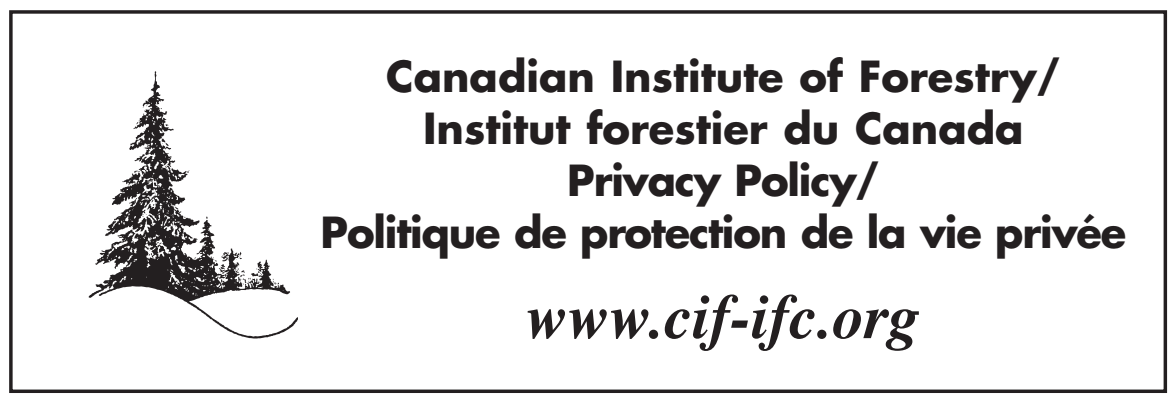




\section{Rapport de la directrice générale}

N ous sommes fiers de vous présenter dans ce numéro du Forestry Chronicle de juillet/août 2005 les récipiendaires 2004-2005 de la Médaille d'Or de l'Institut. L'Institut tient à souligner la performance exceptionnelle de ces étudiants en leur remettant une Médaille d'Or.

La distinction de la Médaille d'Or remonte à plus de 50 ans. K.G. Fensom soulignait dans son historique de l'Institut « Expanding Forestry Horizons - A History of The Canadian Institute of Forestry/Institut forestier du Canada — 1908-1969» que « l'idée de remettre une médaille d'or au meilleur d'entre tous les étudiants en foresterie de l'Université de Colombie-Britannique avait été discutée et approuvée au cours des réunions de la section Vancouver en 1949 ». À la suite d'un concours remporté par M.W Gormely la médaille a pris une forme ronde en or $10 \mathrm{~K}$ comportant un arbre symbolique.

En 1951, M. Harry Dembicki de Trail en C.-B. devient le premier récipiendaire de la médaille d'or de l'Institut forestier du Canada (sections Vancouver et Île de Vancouver). Le numéro de décembre 1952 du Forestry Chronicle mentionne "Que cette médaille d'or, don des sections Vancouver et Île de Vancouver de l'institut forestier du Canada est remise à un étudiant diplômé en foresterie (programmes de B.S.F. ou de B.A.Sc.) qui, de l'avis de Faculté de Foresterie, a fait preuve des meilleurs résultats pour ce qui est de la foresterie en tant que profession et qui a démontré de grandes aptitudes en terme d'attitude, de leadership, de compétition sportive et de résultats académiques ». Fensom indique de plus que " jusqu'en 1953, cette médaille financée conjointement par les sections Vancouver et Île de Vancouver avait été remise chaque année à un diplômé de l'UC.-B. faisant preuve des meilleurs résultats ». $\mathrm{Au}$ cours de la même année, une motion présentée par J.W.Giles et appuyée par R.S. Young fut adoptée lors de l'assemblée générale annuelle de l'Institut. Cette motion proposait : "Que l'Institut forestier du Canada cherche à remettre à chaque année une Médaille d'Or à un étudiant ayant fait preuve de résultats remarquables de la classe des diplômés de chacune des quatre écoles de foresterie canadiennes en fonction de critères qui seront déterminés par le bureau de direction en collaboration avec les doyens des quatre écoles de foresterie ».

La Médaille d'Or comportait à l'origine sur une de ces faces l'inscription " Distinction au mérite - Institut forestier du Canada ». Sur l'autre face, on retrouvait le nom du récipiendaire, l'école et l'année d'attribution du diplôme. "le diplômé qui reçoit cette médaille a été choisi par le doyen en consultation avec les autres membres du corps professoral. À la base de cette sélection de cet étudiant, nous avons retenu ses résultats remarquables non seulement au niveau académique, mais également dans ses activités extracurriculaires comprenant entre autre les activités sportives et étudiantes ».

De 1954 à 1972, les sections associées à l'Université du Nouveau-Brunswick, à
l'Université Laval et à l'Université de Toronto ont commencé à remettre des médailles d'or. Par la suite, entre 1973 et 1991, les diplômés des autres facultés de foresterie se sont vu remettre une médaille d'or. En 1992, afin de reconnaître les établissements techniques et leurs diplômés, le prix de la Médaille d'Or a été remis à un étudiant diplômé de chacune des sept facultés de foresterie et des 21 établissements techniques du Canada.

Cinquante ans plus tard, les critères entourant la remise de la médaille ont peu changé. Le récipiendaire est choisi par le doyen ou le directeur de l'établissement en reconnaissance de ses résultats académiques, sportifs et sociaux remarquables tout au long de sa formation. Toutefois, la médaille n'est plus en or $10 \mathrm{~K}$. La médaille "d'or » contemporaine est montée sur une plaque de bois gravé. La " Médaille d'Or » est habituellement remise par un représentant national ou d'une section au cours de la cérémonie de remise des joncs d'argent de l'Institut forestier du Canada organisée dans chacun des établissements.

Prenez le temps de rencontrer ces personnes remarquables dont nous faisons la présentation dans les pages de ce numéro.

\section{Références}

Le Forestry Chronicle Vol. 28, Décembre 1952, No. 4

Expanding Forestry Horizons - A History of the Canadian Institute of Forestry/ Institut Forestier du Canada - 1908-1969".

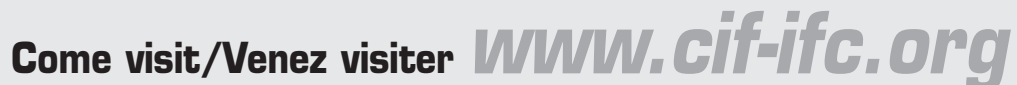 Canadian Institute of Forestry/Institut forestier du Canada}

\author{
* Read about CIF/IFC Activities \& Section News \\ * Read CIF/IFC Position Papers \\ * Learn about Continuing Education opportunities \\ *xplore Job Opportunities \\ **ame a member \\ 橉 View links to other sites
}
* Prenez connaissance des activités du CIF/IFC et des nouvelles des sections
* Prenez connaissance des énoncés de l'Institut
* Informez-vous des possibilités de formation continue
橉 Explorez de nouveaux emplois
橉 Devenez membre de l'Institut
慗 Dirigez-vous vers d'autres sites Internet 


\section{Canadian Institute of Forestry/Institut forestier du Canada}

\section{Suite 606, 151 Slater St., Ottawa, Ontario, Canada K1P 5H3 Tel./Tél: (613) 234-2242 Fax/Téléc: (613) 234-6181 E-mail/courrier électronique: cif@cif-ifc.org Web site/site Internet: www.cif-ifc.org}

The Canadian Institute of Forestry (CIF/IFC) has been the national voice for forestry professionals since 1908. Our membership includes foresters, forest technologists and technicians, educators, scientists and others with a professional interest in forestry. We work in government, industry, research, education and consulting and represent one of the largest professional voices for forestry in Canada.

Our Mission The Mission of the Institute is to advance the stewardship of Canada's forest resources, provide national leadership in forestry, promote competence among forestry professionals, and foster public awareness of Canadian and international forestry issues.

Our Values and Beliefs We believe that members of the Canadian Institute of Forestry (CIF/IFC) should have an intimate knowledge and understanding of Canada's forests. We believe that the stewardship of our forests must be based on an understanding of ecological principles coupled with appropriate inventory and monitoring to ensure that the criteria of ecological integrity and function are maintained within an acceptable sociological framework. Through this understanding, members should promote the intelligent use of Canada's forests to provide a sustainable flow of a wide range of forest commodities, representing a balance of economic, spiritual, recreational and wildlife habitat values. A wide range of forest alternatives is possible, ranging from natural forests to intensively managed tree farms. We believe that the mix of forest uses required to satisfy Canadian needs should be based on an informed public dialogue. Our members should play a constructive role in facilitating such debate.

L'Institut est le porte-parole des professionnels de la foresterie depuis 1908. Nos membres regroupent des forestiers, des techniciens forestiers, des enseignants, des chercheurs et d'autres personnes qui ont un intérêt professionnel pour la foresterie. Nous travaillons pour le gouvernement, l'industrie, en recherche, en éducation et en consultation et nous sommes l'un des plus importants porte-parole en matière de foresterie au Canada.

Notre mission consiste à faire progresser l'intendance des ressources forestières du Canada, d'assumer un leadership national en foresterie, de promouvoir la compétence parmi les professionnels de la foresterie, et chercher à sensibiliser le public sur les questions nationales et internationales en matière de foresterie.

Nos valeurs et nos convictions Nous croyons que les membres de l'Institut forestier du Canada doivent avoir une connaissance approfondie des forêts du Canada. Nous croyons que la gestion de nos forêts en vue d'assurer le maintien de l'intégrité et de la dynamique des écosystèmes dans le cadre d'une perspective sociale acceptable doit s'inspirer d'une compréhension des principes de l'écologie, d'inventaires forestiers fiables et d'un contrôle suivi des travaux d'aménagement. Armés de cette compréhension, les membres de l'Institut se doivent de promouvoir l'utilisation rationnelle des forêts du Canada pour qu'elles demeurent la source inépuisable d'une vaste gamme de produits, et ce tout en conciliant les valeurs qui leur sont associées sur les plans économique, spirituel et récréatif, et de l'habitat faunique. Une large fourchette d'options s'offre à nous, depuis les forêts naturelles jusqu'aux fermes forestières soumises à des régimes d'aménagement intensif. Nous croyons que l'éventail des utilisations de la forêt en vue de répondre aux besoins des Canadiens et Canadiennes doit résulter d'un dialogue éclairé entre les parties intéressées. Nous croyons aussi que les membres de l'Institut se doivent de jouer un rôle de premier plan pour faciliter ce dialogue.

CIF/IFC Executive Committee/Bureau de direction

\begin{tabular}{|c|c|c|c|c|c|}
\hline \multicolumn{6}{|c|}{ President/Président - Michael McLaughlan } \\
\hline \multicolumn{3}{|c|}{$\begin{array}{l}1^{\text {st }} \text { Vice-President } / 1^{\text {er }} \text { vice-président - Chris Lee, R.P.F. } \\
2^{\text {nd }} \text { Vice-President } / 2^{\text {e }} \text { vice-président - Doug Stables, R.P.F. }\end{array}$} & \multicolumn{3}{|c|}{$\begin{array}{l}\text { Past President/Président sortant - Richard L. Macnaughton, R.P.F } \\
\text { Executive Director/directrice générale - Roxanne Comeau, R.P.F. }\end{array}$} \\
\hline Sections & $\begin{array}{l}\text { Directors/ } \\
\text { directeurs }\end{array}$ & $\begin{array}{l}\text { Section Chairs/ } \\
\text { président de section }\end{array}$ & $\underline{\text { Sections }}$ & $\begin{array}{l}\text { Directors/ } \\
\text { directeurs }\end{array}$ & $\begin{array}{l}\text { Section Chairs/ } \\
\text { président de section }\end{array}$ \\
\hline Algonquin & Allan Stinson & Don Willis & Nova Scotia & Jeremy Beal & - \\
\hline Cariboo & Ed Morrice & - & Okanagan & Rod Willis & - \\
\hline Cariboo Chilcotin & Keith Dufresne & - & Orleans & Evelyne Thiffault & - \\
\hline Central Ontario & Peter Newton & Robert Currell & Ottawa Valley & Jeff Young & Tony Bull \\
\hline Klondike & Susan Skaalid & Gregory Cowman & Pacific & - & - \\
\hline Lake of the Woods & Charles Queau & - & Rocky Mountain & Todd Nash & Geoff Clarke \\
\hline Manitoba & Julie Ringash & Trevor Stanley & Saskatchewan & Darryl Sande & - \\
\hline Maritime & Daniel Rogers & Michael Montigny & Skeena & - & - \\
\hline Newfoundland & Wayne Kelly & - & Southern Ontario & Bruce Ferguson & - \\
\hline Northern Ontario & Wally Bidwell & Nikki Wood & Vancouver & Mike Prueter & - \\
\hline Northwestern Ontario & - & Avery Dorland & Vancouver Island & Charlie Klasen & Brian Titus \\
\hline
\end{tabular}




\section{Christopher A. Lee - 68th President of the Canadian Institute of Forestry}

1 t the Canadian Institute of Forestry Annual General Meeting in Prince Albert Saskatchewan, Mr. Chris Lee, R.P.F. will become the Institute's $68^{\text {th }}$ President.

Mr. Lee is currently the Manager for the Canadian Model Forest Network. Over his career, Chris has worked with the forest industry, for Natural Resources Canada, in both the Canadian Forest Service and in corporate functions and for the Canadian Institute of Forestry itself, serving as the Executive Director from 1990 to 1995. Chris has been involved in the Institute as a volunteer, serving on the National Board of Directors for Saskatchewan and Vancouver Island sections and while on the
National Executive he has taken a lead role in promoting forestry as a career of choice. Chris is a member of the Association of British Columbia Forest Professionals and has served on several ABCFP committees, and currently serves on the Board of Directors of the Canadian Wildlife Federation. He has also served on the National Round Table Forestry Panel and the University of Toronto Faculty of Forestry Advisory Committee. Chris graduated from the Univer-sity of Toronto with a Bachelor of Science in Forestry.

Mr. Lee commented that he is honoured to become the President of the Canadian Institute of Forestry, an organization that has a long history

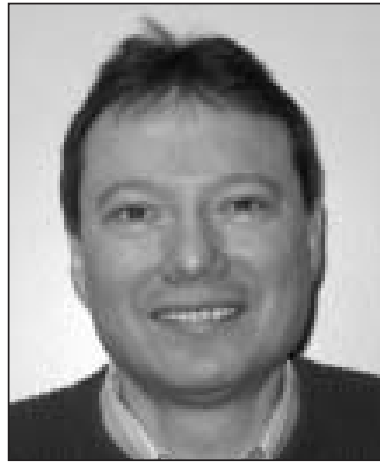

Christopher Lee CIF/IFC President/président 2005-2006

build on credibility and respect. $\mathrm{He}$ looks forward to serving the members of the Institute, and he will continue to work with the Institute's Sections to raise awareness of forestry issues and continue to promote forestry, as a career of choice.

\section{Nomination du 2e vice-président de l'Institut forestier du Canada, un résident de North Bay, Ontario}

M. Michael McLaughlan, président de l'Institut forestier du Canada est fier d'annoncer la nomination de M. Fred Pinto, R.P.F., de North Bay, Ontario, section Algonquin, en tant que $2^{\mathrm{e}}$ vice-président pour l'année 2005-2006.

M. McLaughlan a indiqué que : «M. Pinto est le chef de service du programme des coniferes de la Section sud des Sciences et de l'Information du ministère des Richesses naturelles de l'Ontario et est responsable de l'élaboration de solutions aux enjeux reliés aux politiques et aux pratiques touchant les écosystèmes de coniferes ». Il a joué un rôle déterminant dans l'implantation d'une sylviculture basée sur les écosystèmes en Ontario et il continue d'assumer des fonctions importantes dans le développement et l'implantation des politiques portant sur les vieux peuplements, la régénération et la planification des ressources.

M. Pinto a ajouté qu'en plus de son travail sur les écosystèmes de coniferes, que « l'éducation constitue un élément déterminant en matière de croissance personnelle et d'harmonie sociétale » et qu'en conséquence il cherche à partager ses connaissances et son expertise en donnant un cours de troisième année sur la biologie de conservation à l'Université Nipissing, ainsi qu'en enseignant la planification de l'aménagement forestier aux étudiants du diplôme de techniques forestières du Collège Algonquin à Pembroke.

M. Pinto est un membre actif de l'Institut depuis plusieurs années, en plus de trouver le temps de participer bénévolement à des activités communautaires comme le programme de la ville de North Bay "Community in Blooms ». M. Pinto a ajouté au moment de sa nomination "que puisque nous nous approchons du centenaire de l'Institut ainsi que de celui de plusieurs autres organisations du secteur forestier canadien, nous avons l'occasion unique de présenter au public l'historique et l'avenir de l'intendance de nos forêts. Je suis attiré par ses projets et je cherche à bien répondre aux attentes des membres de l'Institut".

M. McLaughlan a terminé en soulignant que «l'Institut souhaite la

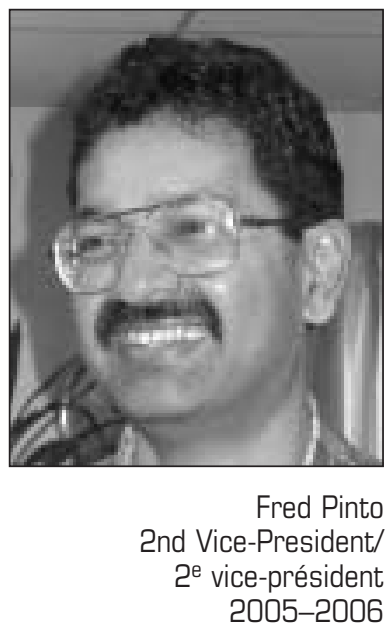

bienvenue à $\mathrm{M}$. Pinto et à son enthousiasme au sein du bureau national de direction. Son mandat débutera en août 2005 immédiatement après l'assemblée générale annuelle de l'Institut forestier du Canada qui aura lieu à Prince Albert en Saskatchewan ». M. Pinto se joindra aux autres membres du bureau de direction pour l'année 2006-2006 qui comprend Chris Lee, président, (Ottawa, $\mathrm{ON})$, Doug Stables, $1^{\text {er }}$ vice-président (Victoria, C.-B.) et Michael McLaughlan, président sortant (Prince Albert, SK). 


\section{Christopher A. Lee 688 président de 'l'Institut forestier du Canada}

I u cours de l'assemblée générale annuelle de l'Institut forestier du Canada qui aura lieu à Prince Albert en Saskatchewan, M. Chris Lee deviendra le $68^{\mathrm{e}}$ président de l'Institut.

M. Lee est présentement le gestionnaire du Réseau canadien des forêts modèles. Au cours de sa carrière, Chris a travaillé pour l'industrie forestière, pour Ressources naturelles Canada, tant au sein du Service canadien des forêts qu'au niveau de la direction générale et pour l'Institut forestier du Canada étant lui-même le directeur général de l'Institut de 1990 à 1995. Chris s'est impliqué bénévolement au sein de l'Institut, en siégeant au conseil national d'administration pour les sections Saskatchewan et Île de Vancouver et alors qu'il faisait parti du bureau de direction, il a joué un rôle déterminant dans la promotion de la foresterie en tant que carrière.

Chris est membre de l'Association of British Columbia Forest Professionals et a participé aux travaux de plusieurs comités et siège actuellement au bureau de direction de la Fédération canadienne de la faune. Il a également participé aux travaux du panel de la Table ronde nationale sur la foresterie et du Comité consultatif de la Faculté de Foresterie de l'Université de Toronto. Chris détient un Baccalauréat en Sciences de la Foresterie de l'Université de Toronto.

M. Lee a indiqué qu'il est honoré d'accéder au poste de président de l'Institut forestier du Canada, une organisation dont le long historique repose sur la crédibilité et le respect. Il s'engage à servir les membres de l'Institut et à collaborer avec les sections afin d'accroître la sensibilisation envers les enjeux forestiers et à poursuivre la promotion de la foresterie en tant que choix de carrière.

La mission de l'Institut forestier du Canada est de « faire progresser l'intendance des ressources forestières $\mathrm{du}$
Canada, d'assumer un leadership national en foresterie, de promouvoir la compétence parmi les professionnels de la foresterie et d'accroître la sensibilisation du public relativement aux enjeux forestiers nationaux et internationaux $»$. Cette mission est réalisée en partie par l'entremise du bureau national situé à Ottawa et par les activités des sections réparties sur tout le territoire canadien. Les membres de l'Institut sont des forestiers des technologistes et des techniciens forestiers, des enseignants, des chercheurs et autres personnes ayant un intérêt professionnel pour la foresterie.

\section{Canadian Institute of Forestry Announces 2nd Vice President from North Bay, Ontario}

$M$ r. Michael McLaughlan, President of the Canadian Institute of Forestry, is pleased to announce Mr. Fred Pinto, R.P.F., from North Bay, Ontario, Algonquin Section, as the Institute's 2nd Vice President for 20052006.

Mr. McLaughlan noted that "Mr. Pinto is the Conifer Program Leader with the Southern Science and Information Section of the Ontario Ministry of Natural Resources where he is responsible for developing solutions to issues related to policy and practice related to conifer ecosystems." He has been instrumental in the implementation of ecosystem-based silviculture in Ontario and he continues to play an important role in the development and implementation of old growth, regeneration and resource planning policy.
Mr. Pinto stated that in addition to his work on conifer ecosystems, that "education is a key ingredient to individual fulfillment and societal harmony" and thus he shares his knowledge and expertise through teaching a third year conservation biology course at Nipissing University, as well teaching a course on forest management planning to people studying for their forest technician diploma at Algonquin College in Pembroke.

Mr. Pinto has been an active member of the Institute for many years, and also finds the time to volunteer for various community activities such as the City of North Bay's "Community in Blooms" program. Pinto noted upon accepting the nomination "As we approach the century mark of the Institute and many other forestry organiza- tions in Canada we have a unique opportunity to engage the public on the past and future stewardship of our forests. I am excited by these prospects and look forward to serving the members of the Institute."

McLaughlan stated that "the Institute welcomes Mr. Pinto and his enthusiasm to the National Executive Committee. He will commence his term in August 2005 following the Canadian Institute of Forestry 2005 Annual General Meeting and Conference in August in Prince Albert, Saskatchewan." Mr. Pinto will join the other members of the National Executive Committee for 2005-2006 - Chris Lee, President (Ottawa, ON); Doug Stables, 1st Vice President (Victoria, BC); Michael McLaughlan, Past President (Prince Albert, SK). 